\title{
Queer studies and religion in Southern Africa: The production of queer Christian subjects
}

\section{Megan Robertson (1)}

Desmond Tutu Centre for Religion and Social Justice, University of the Western Cape,

Bellville, South Africa

\section{Correspondence}

Megan Robertson, Desmond Tutu Centre for Religion and Social Justice, University of the Western Cape, Robert Sobukwe Rd, Bellville 7535, South Africa.

Email: mrobertson@uwc.ac.za

\begin{abstract}
The question of how to write about queer Africa has been a significant debate in scholarship over the last decade. One of the key emerging areas, in the development of 'queer Africa scholarship' has been through the framing of queer African subjects at the intersections with religion and in particular, Christianity. As scholars begin to further imagine queer African subjects as Christian, it is important to explore how and in what ways these subjectivities are constructed. In this article, I apply a qualitative analysis to academic literature that explicitly focuses on, or includes a substantive analysis of queer Christians and/or queer Christianity in Southern Africa. While Southern Africa is not representative of the entire continent, this region is a productive site within which to understand how queer subjects are imagined to be situated, what they are imagined to be doing and how they are imagined to be doing what they do. The context produces queer and LGBTI + (this acronym is sometimes preferred to 'queer' to refer collectively to people who identify as lesbian, gay, bisexual, transgender, intersex and in various other ways as gender and/or sex non-conforming.) subjects who find and make religious homes within legally permissive and restrictive countries and do so through a variety of normative, queer and normatively queer ways, thus revealing religious and sexual contradictions and boundary crossing. This has opened up numerous ways of understanding how religion can be negotiated and transformed in this region. I conclude by examining the theoretical and epistemological possibilities that are revealed through the current
\end{abstract}


imaginings of queer Christian subjects in Southern Africa, as

well as the potential these understandings offer for different

spaces and new discourses in future scholarship.

\section{1 | INTRODUCTION}

The question of how to write about queer Africa has been a significant debate in scholarship over the last decade (see Epprecht, 2013a; 2013b; Matebeni, 2014; Nyeck, 2020). ${ }^{1}$ Due to its potential to be viewed as another colonial imposition, scholars have, in the past, adopted a defiant critique against the use of queer as an identity marker in Africa and a cautionary use of queer theory (Epprecht, 2013a, p. 23-24). Recently however, scholars have begun to more readily position themselves as owners and producers of the fluid, complex and contested meaning of queer as identity, epistemology and theory. In Nyeck's (2020, p. 2) most recent book the 'Routledge Handbook of Queer African Studies', she points out that 'while "queering" Africa is important to some contributors, "Africanizing" queer studies is paramount to others. Still, other contributors see the task of retrieving humanity out of all binaries quintessential'. Importantly the development of this book demonstrates the ways in which scholars studying queer Africa have started to move away from using narrow human rights frameworks which produce the unidimensional queer African subject that Zethu Matebeni was weary of in 2014, and towards more lived and embodied subjectivities which are understood in relation to 'the intersection of political, cultural, socio-economic realities and possibilities' (Nyeck, 2020, p. 1).

One of the key emerging areas of scholarship framing queer African subjects is at the intersections with religion. Theologians and religious studies scholars who are motivated by the lack of nuance in pervading narratives that suggest 'African-ness' is inextricably linked with conservative religious and cultural beliefs and discourses, have positioned religion as a key concept to understanding queers and queerness in Africa. Scholars have focused on various religious traditions in a variety of contexts including Rastafarianism in Zimbabwe (Sibanda, 2016), African Traditional Religions (ATRs) and cultures in South Africa (Mbasalaki, 2020), and Islam in Cape Town (Osman \& Shaik, 2017). However, with the largest number of adherents on the continent as well as being culturally pervasive, Christianity continues to dominate the focus of scholars. As scholars begin to further imagine queer African subjects as Christian, it is important to explore how and in what ways this subject is constructed.

The ways in which academic literature produces queer subjectivities is important for two interrelated reasons. First, how queer subjectivities are imagined, or are unable to be imagined, brings into sharp focus the limitations and possibilities of various theoretical and epistemological frameworks. The conceptual tool of 'imagining' is useful here as it enables me to explore the ways that subjectivities are produced and reproduced through the how scholars have named, positioned and theorised queer identities and experiences. Second, at societal level the queer subjects that we encounter in research has implications for the roles people adopt and how heteronormative society constructs and engages non-normative sexualities and gender non-conforming people (McCarty \& Breneman, 2016, p. 266). 'Imagining' then becomes useful in that it enables me to account for future possibilities of the appropriation and production of meaning and being. In this article, I consider these implications in relation to the ways in which queer Christian subjectivities in Southern Africa have been produced.

In this article, I apply a qualitative analysis to forty articles and book chapters that explicitly focus on or include a substantive analysis of queer Christians or queer Christianity in Southern Africa. I provide a regional rather than continental overview as this enables me to provide a more contextualised analysis of the literature and thus further guarding against homogeneity in my discussion of queer African subjectivities. I focus on exploring the context in which the subject is imagined to be situated, what they are imagined to be doing and how they are imagined to be doing what they do. In the conclusion, I analyse some of the limitations of the current imaginings of queer Christian subjects in Southern Africa and identify different spaces and new discourses for future scholarship. First, I turn my attention to Southern Africa and elaborate on its political and religious significance as a region of focus for this article. 


\section{2 | THE POLITICS AND PUBLICS OF RELIGION AND SEXUALITY IN SOUTHERN AFRICA}

Whilst certain regions in Africa such as Gambia, Kenya, Nigeria and Uganda, have, in recent years, justifiably demanded increased scholarly attention due to the passing of anti-homosexuality legislation, in this article I focus specifically on the context of Southern Africa. Ten countries are generally considered to constitute Southern Africa namely, Angola, Botswana, Eswatini, Lesotho, Malawi, Mozambique, Namibia, South Africa, Zambia and Zimbabwe. The region is characterised by diversity and extreme contrast in relation to sexuality. Countries with governments that support queer-phobia through discourses of conservative Christian and cultural values such as Zimbabwe and Namibia are bordered by South Africa, with its universally lauded constitution which explicitly protects citizens on the basis of sexual orientation. The work on religion and sexuality in this region predominantly focuses on the contexts of South Africa, Zambia and Zimbabwe (for reasons I elaborate on later in this article). Yet, even within these limited contexts, the work that has been done at the intersection of politics, publics and religion provides insight into regional trends and nuances which positions it as a significant context of study. Three significant trends, which I discuss here include, the increased presence and power of Pentecostalism and the public nature of Christianity, the politicisation of HIV/AIDS, and growing scholarly and public decolonial sentiment.

Scholars have argued that Pentecostal-charismatic Christianity is a public religion in Southern Africa (Chipkin \& Leatt, 2011; Homewood, 2016; Van Klinken \& Chitando, 2016) and that it has become central to debates around citizenship and sexuality in many countries in Africa. Grossman (2013) draws on quantitative findings to demonstrate the strong links between the level of adherence to Pentecostalism and the political saliency of LGBT related issues in Africa. In his study, four of the ten countries in Southern Africa, namely, Zimbabwe, South Africa, Angola and Zambia, are named amongst those countries in Africa with more than $20 \%$ of the population affiliating with Pentecostal or charismatic Christianity. Significantly Grossman (2013, p. 24) finds that LGBT related matters are highly salient in the political spheres of these countries. Qualitative studies further support Grossman's conclusions. In Zambia, a significant number of scholars have demonstrated how a combination of state endorsed Christianity characterised by a Pentecostal-charismatic theology and state sanctioned homophobia reinforce the criminalisation and policing of homosexuality in the country (Muwina, 2016; Phiri, 2016a, 2016; Phiri, 2016b; Van Klinken, 2015; Van Klinken \& Phiri, 2015). Of course Pentecostalism is not the only form of Christianity which is entangled in state endorsed queer-phobic sentiments. In fact, historically the majority of so-called mainline Protestant churches have played a significant role in the politics of race, gender and sexuality in the region. I elaborate on how both Pentecostal and mainline churches are framed in relation to queer Christian subjects in my analysis below, here it is to note that the public nature of Christianity in this region makes this a significant site for the study of religion and sexuality.

The continued spread of HIV/AIDS has also politicised discourses on sex and sexuality in the region. Chitando (2007) argues that public discourses have historically emphasised the heterosexual transmission of the virus. According to Epprecht (2008), even important scholarly texts aimed at health care professionals sometimes went so far as to limit HIV transmission in Africa to three heteronormative modes namely, heterosexual intercourse, intravenous injection and mother-to-child transmission. The wishing away of any linkages between HIV transmission and same-sex sexual relations was a deliberate attempt to avoid the association of HIV with homosexuality and, thus to break down the stigma surrounding those living with it. In turn, however, Van Klinken and Gunda (2012, p. 122) argue that, 'the problem of stigma on HIV and AIDS has been solved by stigmatising homosexuality into nonexistence'. The invisibility of homosexuality from discussions on HIV and AIDS in the region has bolstered the rhetoric which claims that it is a western, imperialist invention-a discourse which has influenced the ways that politics and Christian churches have engaged with queer sexualities.

This same rhetoric that asserts that queer sexualities are inherently un-African has also been co-constituted by increased enthusiasm for decolonial sentiment. Yet, while African religious and political leaders in the region have leveraged these discourses to gain political support and power (Msibi, 2011), they have also been shown to be 
supported and sustained by religious factions outside of Africa, most notably right-wing American Roman Catholics, Mormons and evangelicals, who gain ideological and social power through the theological demonisation of homosexuality (Kaoma, 2012, 2016). However, the globalisation of queer rights movements and Pride celebrations continue to take place in highly gendered and racialised ways, and has often marginalising queer people of colour, most notably women and trans-persons (Matebeni, 2017). The combination of these various developments has bolstered the fervour with which Christian circles in Southern Africa claim queer sexuality to be a 'white', western invention.

The complexity of a region which juxtaposes conservative 'Christian nations' with constitutionally progressive and pluralistic ones, with experiences of both violence as well as liberation for queer people, provides fertile ground to examine the various African and queer subjectivities and embodiments emerging from scholarship. Further cross-cutting regional trends of politically entangled Christianity and religious and politically fuelled queer-phobia provides a productive site of investigation for the ways in which the emergence of queer Christianities and understandings of queer Christian subjects could talk back to the politics and power implicated in debates about African sexualities.

\section{3 | THE PRODUCTION OF QUEER CHRISTIAN SUBJECTS IN SOUTHERN AFRICA}

In the section which follows, I explore how scholarship has thus far imagined queer Christian subjects in Southern Africa. In seeking to analyse how queer Christians are imagined in this context, I use three key questions to focus my enquiry. The first is 'where are they?' In answering this I analyse the contexts in which scholars have sought to understand queer Christian experiences. The second question is 'what are they doing?'. This question asks how scholars see queer African Christian subjects interacting with the contexts within which they are located. Finally I am interested in the question of, 'how do they do what they do?'. This question addresses issues of framing and explores the limitations and possibilities that current theoretical and epistemological frameworks hold for how queer and queering is imagined in Southern Africa.

\section{1 | Where are they?}

As noted in the discussion of Southern Africa, queer Christian subjects are usually imagined within the borders of Zambia, Zimbabwe and South Africa. More research is required to understand the reasons for this disproportionate focus, however, it is likely that anti-queer statements and religious and culturally loaded declarations made by controversial leaders such as Robert Mugabe in Zimbabwe (Homewood, 2016, p. 244-245; Manyonganise, 2016), Minister of Justice Winter Kabimba in Zambia (Van Klinken, 2015, p. 951) and Jacob Zuma in South Africa (Seale, 2006) have drawn attention to these contexts. It may also be the case that scholars looking to understand the ways in which queer African people negotiate and transform their contexts in empowering ways find this limited in certain countries more than others. Van Klinken (2019, p. 9), for example, attributes the move in his scholarship from Zambia to Kenya, in part, for precisely this reason. It may, therefore, be the case that scholars have found other countries in the region unproductive sites for similar research. South Africa, on the other hand, continues to provide a case of legal exceptionalism within which to explore queer Africa and therefore continues to garner scholarly interest. Furthermore, because queer sexuality is not a legally punishable offence in South Africa, access to participants and issues of safety and ethics is perhaps relatively simpler than many other countries.

Interestingly despite the fact that South Africa borders numerous other countries with more restrictive laws against queer sexuality, and despite queer theories' propensity for exploring movement and boundary crossing, scholars of religion and theology have not explored the ways that queer Christians move across national boundaries within (or outside) the region. While a few studies have focused on sexual or gender refugees in Southern Africa, as 
is the case with many gender-sex studies, religion does not feature as a significant part of these analyses (Camminga, 2018). In fact, studies which have taken the intersection of Christianity seriously in queer subjects' experiences in Southern Africa, have been more interested at exploring the queer subject who remains within their own country despite anti-homosexual legislation, rather than those that move (see e.g., Phiri \& Nadar, 2018).

Within these national contexts, queer Christian subjects can often be found in the Church. In the last 5 years scholars have begun to move away from looking at Christian churches responses to homosexuality and instead focus on queer experiences of Christianity and the church. In Zambia and Zimbabwe, Pentecostal and Charismatic churches feature prominently in the literature (Homewood, 2016; Van Klinken, 2015). Other studies do not focus on a particular strand of Christianity but include participants from various mainline, Pentecostal and African Independent churches (Muparamoto, 2016). Literature on South Africa is significantly skewed towards a focus on so-called mainline churches, which include many of the Protestant denominations in South Africa. This is not surprising as Christian theology in South Africa continues to associate Pentecostal and Charismatic Christianity with 'hoax' pastors who target naïve congregants with false promises of harmful healing practices such as spraying Doom (a brand of bug spray) on them (see e.g., Forster, 2019). By positioning Pentecostal-Charismatic Christianity in South Africa as queer itself, religious and theological scholars have not taken this context seriously in light of issues surrounding sexuality.

What scholars working in South Africa have taken seriously is the influence and impact that debates within mainline churches have on public life in Southern Africa. Unlike engagements with Pentecostalism in Zambia and Zimbabwe, scholars tend to focus on specific denominations and the internal politics, theologies and doctrines which either shape the church's stance on same-sex debates or which impact how queer Christians experience those denominations. This includes the Dutch Reformed Church (Loggerenberg, 2015; Van der Walt, 2016; Vorster, 2008) and the Methodist Church of Southern Africa (Dlamini, 2019; Robertson, 2020; Sipungu, 2019). Scholars such as Palm (2019) have also engaged in research with local NGOs in South Africa and focused on experiences of queer persons and other leaders and congregants in individual congregations including NG Kerk Bloubergstrand (Dutch Reformed Church), Central Methodist Mission (Methodist), Gugulethu Uniting Presbyterian Church (Presbyterian) and Rondebosch United Church (Congregational/Presbyterian). LGBT affirming congregations in South Africa have also been studied with both Palm and Potgieter and Reygan (2011) focussing on the Good Hope Metropolitan Community Church in District Six in Cape Town. However, these enquiries remain on the margins of the debate. Most of this literature locates the issues of mainline churches in ecclesiastical or theological terms which frame it as an 'in-house' issue and do not necessarily engage with the idea of Christianity in mainline churches as a public religion. However, by and large the queer Christian in Southern Africa is associated with an ecumenical idea of Christianity. While the influence of the Catholic Church has been studied in contexts such as Cameroon (Nyeck, 2016), there is no study which I could find that focused on it within Southern Africa. This is perhaps because historically Catholicism has not played a significant role in public morality and politics in this region.

Examining participants in church on one hand, challenges the idea that one can only be queer in queer spaces. Homewood (2016), for example, argues that churches in Zimbabwe have become 'great places for cruising' (p. 248), whilst larger churches have 'gay subcultures' or 'enclaves' (p. 248). Yet, while queer Christians can sometimes be found in other institutions like the university (Nkosi \& Masson, 2017), the literature suggests that once they leave the Church, Christianity no longer forms a significant part of their meaning-making system.

An interesting and unique contribution from literature on this region is the ways in which some queer subjects' experiences are situated on a spectrum including both Christianity and ATRs and/or cultural beliefs. Van Klinken and Otu (2017), for example, look at the autobiographic narrative of Nkunzi Zandile Nkabinde in the book 'Black Bull, Ancestors and Me: My Life as a Lesbian Sangoma'. In furthering Chidester's (2012) concept of 'wild religion', the authors demonstrate how Nkabinde's narrative blends '...Zulu indigenous religion and Christianity', which is coconstituted by her 'blending of lesbian and sangoma identities' (Van Klinken \& Otu, 2017, p. 73). This analysis of Nkabinde's narrative provides an insight into the fluid situatedness of queer Christian subjectivities in Southern 
African. Through the authors analysis we see that Nkabinde's subjectivity is not placed statically in relation to a Church but is rather positioned as a fluid queering of religious boundaries and religious, gendered and sexual identities.

\subsection{What are they doing?}

While some studies show that queer people in Southern Africa sometimes reject Christianity or, more commonly, a particular church (Chamane, 2017; Hodgeson, 2020; Muparamoto, 2016; Phiri \& Nadar, 2018, p. 78; Sipungu, 2019; Stobie, 2014, p. 11), the majority of studies are concerned with what queer Christians do when they remain in their Church.

Contrary to earlier scholarship which viewed queer Christians only as aliens in the church (Germond \& De Gruchy, 1997), scholars have explored the work of queer people as active participants and leaders within their churches. Scholarship shows that queer Christian subjects occupy roles as clergy (Dlamini, 2019; Robertson, 2020), altar boys (Phiri \& Nadar, 2018, p. 79), serving in children's ministry (Hodgeson, 2020, p. 106) and reading the Bible, praying and worshipping on ordinary Sunday's in church (Chamane, 2017, p. 43-44; Muparamoto, 2016, p. 149; Phiri, 2016b, p. 166). Often these activities enable participants to draw strength, encouragement and experience a sense of love within these spaces. Queer Christians can also be found to be engaging in religious rites or ritual such as funerals and weddings. In some instances queering these religious rites, for example, through the way in which Zanele Muholi dressed in masculine attire at her mother's Catholic funeral and attributing the Church's lack of protest as acceptance of her queerness (Stobie, 2014, p. 9). Or in other cases producing their own queer religious rites and rituals such as coming out (Chamane, 2017; Homewood, 2016, p. 252) and experiencing their call to the ministry (Dlamini, 2019). In short, the queer Christian in Southern Africa can often be found doing Church in normative, queer and normatively queer ${ }^{2}$ ways.

Particularly interesting is the more embodied and often transgressive nature of the acts attributed to trans subjectivities and/or those who cross and dwell (Tweed, 2006) between Christianity and ATRs. For example, healing is an activity that is more common amongst those who occupy this queer religious space (Hodgeson, 2020; Stobie, 2014). Hodgeson (2020), also offers us a look at the embodied nature of queer dreaming. In her autobiographical engagement with religion and sexuality, dreaming becomes central to the narrative of shifting between Anglican, Pentecostal and Catholic Christianity and African spirituality and traditional healing. She argues her identity is central to the ways in which she understands 'spirituality as existing beyond Christian and Western frames of references' and it is through the activity of dreaming that she makes sense of this journey as she continues to make sense of her spirituality (Hodgeson, 2020, p. 129). Studies with participants who flow between Christianity and ATRs also demonstrate that queer subjects perform acts of healing. Hodgeson (2020, p.111) serves as one example as she describes how she physically feels her ability to heal.

One of the more transgressive acts that we find subjects engaging in when situated at the fluid intersections of Christianity and ATRs, is the performing and embodying of the erotic. While this still remains a marginalised characterisation of queer Christians (Van Klinken, 2019, p.93-97), scholars have begun to transgress the taboo at these queer intersections of religious traditions. Van Klinken and Out (2017), for example, find the erotic performed in Nkabinde's story as she explains having sex with other women and how her male ancestor, Nkunzi, uses her body to fulfil his own desires. In Homewood's (2016) work, for example, he observed an act of healing between a pastor rumoured to be gay and young man from the congregation. Homewood demonstrates the erotic in this healing similarly to how Nadar and Jodamus (2019) theorise the eroticism of Pentecostal worship, and positions this as an example of the erotic in public. Although he tempers this by also demonstrating the precariousness of public sex, using the example of Innocent who stopped attending church after he had ejaculated in his pants after the prophet came close and produced 'feelings of religious ecstasy' (Homewood, 2016, p. 255). 


\subsection{How do they do what they do?}

The literature discussed above suggest that scholars have moved away from the construction of the secular, anti-Christian and oppressed queer subject in Southern Africa, to the production of a subject who is able to actively participate in Christianity through their church and who embodies the erotic, at times even within that church. I now move on to ask, how is it that these queer subjects are able to do what was seemingly unimaginable in the previous decade?

Scholars have shown that the queer Christian in Southern Africa makes use of strategies comparable to those of queer Christians in the United States and Europe to negotiate the apparent contradiction between their religious and sexual identities and thus to make a home for themselves in church. For example, in the same way that participants in Rodriguez and Oullette's (2000) study, who are part of a gay-affirming Church in New York, compartmentalised their identities through a temporary denial of either their sexuality or religiosity, Sipungu (2019) identifies two queer Christian subjectivities in the Eastern Cape of South Africa who, within the Methodist Church of Southern Africa which is not fully affirming, adopts similar strategies. 'Gay Methodist lifestylers' (Sipungu, 2019, p. 6), as he terms them, negotiate their identities by centralising 'gayness' while rendering other identities, such as their identity as Methodist, as inferior and thus as something which could be discarded at any time. 'Gay Methodist commuters' (Sipungu, 2019, p. 8), on the other hand, migrate between different expressions of identities by 'turn[ing] on their gayness' in spaces where this is acceptable such as online dating sites and social circles and off in other non-acceptable spaces. Similarly, Muparamoto (2016) demonstrates how the same-sex loving participants in his study (four who identify as lesbian and nine as gay) in Zimbabwe conceal sexuality from those in church and thus maintained both identities but in separated spheres of their life.

One of the emerging trends in the research which holds enormous possibility for exploration in emerging scholarship is the idea that, contrary to popular narratives, queer Christians in Southern Africa does resist and subvert normative ideas surrounding their religion and sexuality. In this sense they do not only make trade-offs in an overly oppressive society as narratives of negotiation may suggest, but instead produce counter narratives and counter theologies which they use to make meaning of their experiences as well as transform their contexts.

In Van Klinken' and Phiri's (Phiri, 2016a, 2016b; Van Klinken, 2015; Van Klinken \& Phiri, 2015) work with Zambian gay men, Thembani Chamane's work with Zulu gay men (2017) as well as Muparamoto's (2016) research in Zimbabwe, they show how participants have agency and resist discourses which frame them as evil and sinful by subscribing to and asserting more universal understandings of love (in relationship with others and God). A queer image of God is created by participants in which universal love and compassion is emphasised. Participants emphasise the ways in which they were created in the image of God or created by God and cite this as evidence of God's acceptance of them. In this way, queer Christians are able to co-produce theological understandings with their religious leaders and their church through various resistance strategies. Others also reclaimed the language used to describe their identities and thus shift the narratives around their sexuality and religion. For example, in Phiri's (2016b) study participants resisted the terminology of men who have sex with other men in favour of men who love other men, thus shifting the emphasis of sexual acts in relation to their identities and experiences and instead highlighting their relational experiences and theological interpretations of love. These various resistance strategies demonstrate how interpretations of Scripture and Christianity (informed by lived experiences) can be produced which challenges the taken-for-granted hetero-patriarchal readings of sacred texts which many churches hold onto.

In some ways, the previous examples echo what has been found in other contexts which have explored how queer theologies have been developed. Scholars in Southern Africa have, however, also begun to apply and expand on post- and decolonial framings of agency in order to explore the nuance and complexity in the various ways the queer Christian in Southern Africa resists queer-phobic and heteronormative beliefs and attitudes. Phiri and Nadar's (2016) work for example uses borderland theory to imagine resistance of domination in Zambia in both overt and covert ways. They find that while participants engage in overt forms of resistance in the form of 
'non-masculine dressing, walking, sitting and general mannerisms, assuming feminine gender and sexual roles in their sexual relationships, within their families and communities,' participants also participated in more subtle means of resistance 'by maintaining a semblance of heterosexuality to delude the communal gaze, in spite of being gay' (Phiri \& Nadar, 2018, p. 190). In both Homewood's (2016, p. 244) research in Zimbabwe as well as my research on queer Methodist clergy in South Africa (Robertson, 2020), we also find evidence of more expansive conceptualisations of resistance.

Homewood positions his work in relation to popular western conceptualisations as posited by Berlant and Warner in 1998, which position queer resistance as necessarily anti-normative and subversive. Homewood (2016), however, cites instances of 'erotic healing' (p. 250), the relative safety of Vaspostori churches in which prophets are only able to detect heterosexual sin (p. 251-252), and participants' use of normative language of Christian conversion to describe their meaning-making behind their sexuality (p. 253) as instances of resistance within the normative structures of the church and Christianity. Similarly in my work I demonstrate that by adopting a normative Methodist and clerical identity and by the non-naming of their sexual identities, participants resist institutional rhetoric which excludes them from the normative Christian space (Robertson, 2020). In both texts, participants perform their queerness in multiple ways within the normative space of church-this in itself demonstrates the pluralistic ways in which resistance within (rather than only against) normative systems can take place.

\section{4 | IMAGINING FUTURE PRODUCTIONS OF THE QUEER CHRISTIAN IN SOUTHERN AFRICA}

Southern Africa remains a poignant site of enquiry that provides a geo-political snapshot of the broad continental and globalised debates about African sexuality. It provides a site for challenging imagined universalised ideas of queer rights and the secularisation of queer freedoms. It is a site where anti-colonial sentiment, decolonial commitments and queer possibilities intersect. In response to calls for theory and theology to proceed from the epistemological starting point of lived experience, scholars have begun to generate more complex and nuanced pictures of queer Christian subjectivities within this regional and political terrain.

We are no longer left with the oppressed black queer African, struggling to survive in a conservative religious and cultural context. Rather, by examining religion as an important intersection in the lives of queer subjects, the literature has shown the variety of ways in which religion and sexuality is negotiated, subverted and lived. We have found that the queer Christian subjects in Southern Africa are able to make themselves at home (although at times tenuously) even within countries which proliferate Christian nationalist and anti-queer discourses. Furthermore, they are not only situated within national borders but dwell within the borders of church. The queer Christian subjects depicted in the literature actively participate and sometimes lead various churches. At times even finding and producing queer subcultures and enclaves within these normative spaces. Significantly, we find that queer subjects in Southern Africa are not homogenous but the lives of gay, lesbian and transgender people are reflected. Queer Christian subjects have been positioned as central to the work of transforming church and society. Through dialogue, negotiation and resistance queer Christian subjects seems to be actively engaged in the process of change.

Some of the more innovative work with implications for queer theory and queer studies of religion has come from the ways that postcolonial framings of queer resistance have been imagined. The ordinary, everyday and varied agencies of queer Christian subjects opens up possibilities for scholars to reimagine the ways in which religion and sexuality intersect and shape one another. The inclusion of subjectivities which queer the boundaries of Christianity and ATRs in recent scholarship provides some of the more unique and queer possibilities of these agencies. In the narratives and experiences of these subjects, we are able to explore the intersections of religion and sexuality outside the bounds of church and make meaning of the queerness of dreaming, healing and sex. 
Within these contexts and through these activities, we are presented with distinctively queer ways in which subjects embody and perform their sexualities and religions. These narratives not only provide insight into the ways in which African Christianities, ATRs and cultures produce queer sexualities but also how queer sexualities produce religion and subvert normative religious boundaries.

That being said there are still numerous manifestations of queerness which present productive yet under examined sites of knowledge production in this area. There are, for example, definite neglected geographies of exploration. We know little about queer Christians in Angola, Botswana, Eswatini, Lesotho, Malawi, Mozambique and Namibia or even the reasons for why these contexts have not been studied. In addition, while queer Christian subjects have found a tenuous home in the church, their religion seems to be confined to these boundaries in the literature. The intersection of Christianity and sexuality in media, art, bars, clubs, schools or other everyday spaces has been left largely unexamined. This gap is significant in light of arguments that Christianity in Southern Africa is a public religion with important consequences for political and public discourses on sexuality. Bisexuality is also only explicitly considered in one text (Hodgeson, 2020) in my survey of the literature, and continues to be marginal even to transgender subjectivities. The queering which happens at the intersections of ATRs and Christianity also opens up possibilities for comparative studies of religion and sexuality in the region. It also brings up possibilities for exploring other instances of religious and cultural crossing and dwelling, for example, between Islam and Christianity in Cape Town, in particular manifestations of New Religious Movements or in syncretic traditions and rituals. These multiple and varied ways of broadening our conceptualisation of queer Christian subjectivities in Southern Africa, and Africa more broadly, has the potential to expand queer theories and to imagine new possibilities of queering religion and sexuality.

\section{5 | INFORMATIVE}

In this article I apply a qualitative analysis to literature that explicitly focuses on or includes a substantive analysis of queer Christians or queer Christianity in Southern Africa. The findings suggest that the literature has produced queer and LGBTI + subjects who find and make religious homes within legally permissive and restrictive countries and do so through a variety of normative, queer and normatively queer ways. This has opened up numerous ways of understanding the ways in which religion can be negotiated and transformed in this region.

\section{ACKNOWLEDGMENTS}

This work is based on research supported by the National Research Foundation of South Africa under the auspices of the Desmond Tutu Chair in Religion and Social Justice (Grant Number: 118854).

\section{ORCID}

Megan Robertson iD https://orcid.org/0000-0002-2861-152X

\section{ENDNOTES}

${ }^{1}$ While I largely use queer as an identity marker and a theoretical framing in this paper, when referencing literature I also use various other acronyms and terms to reflect the ways the authors discuss their participants and frame their research in their work.

2 One of the critiques of queer theory is that it produces queer norms in relation to performing 'queerness' as well as resistance and subversion (see Cohen, 1997).

\section{REFERENCES}

Camminga, B. (2018) 'Gender refugees' in South Africa: The 'common-sense' paradox. Africa Spectrum, 53(1), 89-112. Available from: https://doi.org/10.1177/000203971805300105 
Chamane, T. (2017) An exploration of how Zulu gay men negotiate their Christian and cultural beliefs in the process of coming out. Massachusetts: UKZN.

Chidester, D. (2012) Wild religion: Tracking the sacred in South Africa. California: University of California Press.

Chipkin, I. \& Leatt, A. (2011) Religion and revival in post-apartheid South Africa. Focus, 62, 39-46.

Chitando, E. (2007) Living with hope: African churches and HIV/AIDS (Part 1). Switzerland: WCC Publications.

Cohen, C. (1997) Punks, Bulldaggers, and welfare queens: The radical potential of queer politics? GLQ: A Journal of Lesbian and Gay Studies, 3(4), 437-465. Available from: https://doi.org/10.1215/10642684-3-4-437

Dlamini, N. (2019) The implications of queer sexuality in ministry: The experiences of queer clergy in the methodist Church of Southern Africa, Master's thesis. Retrieved from https://ukzn-dspace.ukzn.ac.za/

Epprecht, M. (2008) Heterosexual Africa? The history of an idea from the age of exploration to the age of AIDS. Athens: Ohio University Press.

Epprecht, M. (2013a) Hungochani: The history of a dissident sexuality in Southern Africa, 2nd edition. Montreal \& Kingston: McGill-Queen's University Press.

Epprecht, M. (2013b) Sexuality and social justice in Africa: Rethinking homophobia and forging resistance. London \& New York: Zed Books.

Forster, D. (2019). From 'prophetic witness' to 'prophets of doom?'-the contested role of religion in the South African public sphere. In Forster, D., Gerle, E., \& Gunner, G. (Eds.) Freedom of Religion at Stake: Competing claims among faith traditions, states, and persons. Eugene, Oregon: Pickwick Publications, pp. 18-39.

Germond, P. \& De Gruchy, S. (1997) Aliens in the household of God: Homosexuality and the christian faith in South Africa. Cape Town: David Philip Publishers.

Grossman, G. (2013) Renewalist Christianity, political competition and the political saliency of LGBTs in sub-Saharan Africa. The Journal of Politics, 77(2), 337-351. Available from: https://doi.org/10.1086/679596

Hodgeson, A. (2020) Can black queer feminists believe in God? An exploration of feminism, sexuality and the spiritual. In: Nyeck, S. (Ed.), Routledge Handbook of queer African studies (pp. 105-112). Oxon: Routledge.

Homewood, N. (2016) 'I was on fire': The challenge of counter-intimacies within Zimbabwean Christianity. In: Van Klinken, A. \& Chitando, E. (Eds.) Public religion and the politics of homosexuality in Africa. London: Routledge, pp. 243-259.

Kaoma, K. (2012) Colonizing African values: How the U.S. Christian right is transforming sexual politics in Africa. Somerville: Political Research Associates.

Kaoma, K. (2016) An African or un-African sexual identity? Religion, globalisation and sexual politics in sub-saharan Africa. In: Van Klinken, A. \& Chitando, E. (Eds.) Public religion and the politics of homosexuality in Africa. London \& New York: Routledge, pp. 113-129.

Loggerenberg, M. (2015) The 2007 Dutch Reformed Church synod resolution: Impact on gay ministers. HTS Teologiese Studies/Theological Studies, 71(3), 1-9. Available from: https://doi.org/10.4102/hts.v71i3.2894

Manyonganise, M. (2016) 'We will chop their heads off': Homosexuality versus religio-political grandstanding in Zimbabwe. In: Van Klinken, A. \& Chitando, E. (Eds.) Public religion and the politics of homosexuality in Africa. London \& New York: Routledge, pp. 63-77.

Matebeni, Z. (2014) How NOT to write about queer South Africa. In: Matebeni, Z. (Ed.) Reclaiming Afrikan; queer perspectives on sexual and gender identities. Cape Town: Modjaji Books, pp. 61-64.

Matebeni, Z. (2017) Southern perspectives on gender relations and sexualities: A queer intervention. Revista De Antropologia, 60(3), 26-44. Available from: https://doi.org/10.11606/2179-0892.ra.2017.141826

Mbasalaki, P. (2020) Women who love women: Negotiation of African traditions and kinship. In: Nyeck, S. (Ed.), Routledge Handbook of queer African studies (pp. 37-48). Oxon: Routledge.

McCarty, R. \& Breneman, J. (2016) Critical realism and LGBTIQ rights in Africa. In: Van Klinken, A. \& Chitando, E. (Eds.) Public religion and the politics of homosexuality in Africa. London \& New York: Routledge, pp. 260-272.

Msibi, T. (2011) The lies we have been told: On (homo) sexuality in Africa. Africa Today, 58(1), 55-77.

Muparamoto, N. (2016) Enduring and subverting homophobia: Religious experiences of same-sex loving people in Zimbabwe. In: Chitando, E. \& Van Klinken, A. (Eds.) Christianity and controversies over homosexuality in contemporary Africa. London \& New York: Routledge, pp. 143-156.

Muwina, D. (2016) Christianity, homosexuality and public politics in Zambia. In: Chitando, E. \& Van Klinken, A. (Eds.) Christianity and controversies over homosexuality in contemporary Africa. London \& New York: Routledge, pp. 85-97.

Nadar, S. \& Jodamus, J. (2019) 'Sanctifying sex': Exploring 'indecent' sexual imagery in Pentecostal liturgical practices. Journal for the Study of Religion, 32(1), 1-20. Available from: https://doi.org/10.17159/2413-3027/2019/v32n1a5

Nkosi, S. \& Masson, F. (2017) Christianity and homosexuality: Contradictory or complementary? A qualitative study of the experiences of christian homosexual university students. South African Journal of Higher Education, 31(4), 72-93. Available from: https://doi.org/10.20853/31-4-891 
Nyeck, S. (2016) Queer fragility and christian social ethics: A political interpolation of the catholic church in Cameroon. In: Chitando, E. \& Van Klinken, A. (Eds.) Christianity and controversies over homosexuality in contemporary Africa. London \& New York: Routledge, pp. 110-124.

Nyeck, S.N. (Ed.) (2020) Routledge Handbook of queer African studies. New York: Routledge.

Osman, M. \& Shaikh, S. (2017) Islam, muslims and politics of queerness in Cape Town. Journal of Gender and Religion in Africa, 23(2), 43-67.

Palm, S. (2019) From exclusion to embrace: Re-imagining LGBTIQ belonging in local South African church congregations. Retrieved from http://blogs.sun.ac.za/urdr/files/2019/03/FromExclusiontoEmbraceResearchReport.April2019.pdf

Phiri, L. \& Nadar, S. (2018) To move or not to move! Queering the borders and faith in the context of diverse sexualities in Southern Africa'. In: Machado, D., Turner, B. \& Wyller, T. (Eds.) Borderland religion: Ambiguous practices of difference, Hope and beyond. Abingdon: Routledge, pp. 76-86.

Phiri, L. (2016a) 'Construction sites': Exploring queer identity and sexuality at the intersections of religion and culture in Zambia, Doctoral dissertation. Retrieved from https://ukzn-dspace.ukzn.ac.za/

Phiri, L. (2016b) 'Born this way': The imago Dei in men who love other men in Lusaka, Zambia. In: Chitando, E. \& Van Klinken, A. (Eds.) Christianity and controversies over homosexuality in contemporary Africa. London \& New York: Routledge, pp. 157-170.

Potgieter, C. \& Reygan, F. (2011) Disruptive or merely alternative? A case study of a South African gay church. Journal of Gender and Religion in Africa, 17(2), 58-76.

Robertson, M. (2020) Called and queer: Exploring the lived experiences of queer clergy in the methodist Church of Southern Africa, Doctoral dissertation. Retrieved from http://etd.uwc.ac.za/

Rodriguez, E. \& Oullette, S. (2000) Gay and lesbian Christians: Homosexual and religious identity integration in the members and participants of a gay-positive church. Journal for the Scientific Study of Religion, 39(3), 333-347.

Seale, L. (2006,September 27) Zuma's anti-gay comments lead to backlash. IOL. Available from: https://www.iol.co.za/news/ politics/zumas-anti-gay-comments-lead-to-backlash-295249

Sibanda, F. (2016) One love, or chanting down same-sex relations? Queering Zimbabwean rastafari perspectives on homosexuality. In: Van Klinken, A. \& Chitando, E. (Eds.) Public religion and the politics of homosexuality in Africa. London \& New York: Routledge, pp. 180-196.

Sipungu, T. (2019) Gay men's identity negotiation strategies within the methodist church of southern Africa in grahamstown, South Africa. South African Review of Sociology, 50(1), 51-64. Available from: https://doi.org/10.1080/ 21528586.2019.1630297

Stobie, C. (2014) 'The devil slapped on the genitals': Religion and spirituality in queer South Africans' lives. Journal of Literary Studies, 30(1), 1-19. Available from: https://doi.org/10.1080/02564718.2014.887620

Tweed, T. (2006) Crossing and dwelling: A theory of religion. Cambridge: Harvard University Press.

Van der Walt, C. (2016) Is 'being right' more important than 'being together'? Intercultural bible reading and life-giving dialogue on homosexuality in the Dutch reformed church, South Africa. In: Chitando, E. \& Van Klinken, A. (Eds.) Christianity and controversies over homosexuality in contemporary Africa. London \& New York: Routledge, pp. 125-140.

Van Klinken, A. (2019) Kenyan, Christian, queer: Religion, LGBT activism, and the arts of resistance in Africa. Pennsylvania: The Pennsylvania State University Press.

Van Klinken, A. \& Chitando, E. (Eds.) (2016) Public religion and the politics of homosexuality in Africa. London \& New York: Routledge.

Van Klinken, A. \& Otu, K. (2017) Ancestors, embodiment and sexual desire: Wild religion and the body in the story of a South African lesbian sangoma. Body and Religion, 1(1), 70-87. Available from: https://doi.org/10.1558/bar.33129

Van Klinken, A. \& Phiri, L. (2015) 'In the image of God': Reconstructing and developing a grassroots African queer theology from Urban Zambia. Theology and Sexuality, 21(1), 36-52. Available from: https://doi.org/10.1080/ 13558358.2015.1115598

Van Klinken, A. (2015) Queer love in a 'christian Nation': Zambian gay men negotiating sexual and religious identities. Journal of the American Academy of Religion, 83(4), 947-964. Available from: https://doi.org/10.1093/jaarel/lfv073

Van Klinken, A. \& Gunda, M. (2012) Taking up the cudgels against gay rights? Trends and trajectories in African Christian theologies on homosexuality. Journal of Homosexuality, 59(1), 114-138. Available from: https://doi.org/10.1080/ 00918369.2012 .638549

Vorster, J. (2008) Problematising the development of same-sex rhetoric in selected reformed denominational traditions in South Africa. Scriptura, 99, 321-336. Available from: https://doi.org/10.7833/99-0-673 


\section{AUTHOR BIOGRAPHY}

Dr Megan Robertson is a postdoctoral fellow under the auspices of the Desmond Tutu SARCHI Chair in Religion and Social Justice (Grant No. 118854). She is also an associate lecturer/researcher in the Desmond Tutu Centre for Religion and Social Justice. Her research interests lie at the intersections of religious and queer studies. She also has a keen interest in developing method and pedagogical practice in these areas. Robertson completed her doctoral studies in April 2020. Her dissertation explored the lived experiences of queer clergy in the Methodist Church of Southern Africa.

How to cite this article: Robertson M. Queer studies and religion in Southern Africa: The production of queer Christian subjects. Religion Compass. 2020;e12385. https://doi.org/10.1111/rec3.12385 